\title{
Editorial
}

\section{The tobacco industry: the pioneer of Fake News}

\author{
Martin McKee \\ London School of Hygiene and Tropical Medicine, London, UK
}

When Italy introduced a comprehensive ban on smoking in public places in 2005, it was in the forefront of tobacco control in Europe, with the pioneers, Ireland and Norway, having done so only a year previously. The Italian ban achieved very high levels of compliance, ${ }^{1}$ attracting strong public support. A Eurobarometer study conducted in 2009 finding that it was welcomed by $95 \%$ of Italians, more than in any other country in Europe. ${ }^{2}$

The ban had been introduced in the face of intense opposition from the tobacco industry. Its arguments took several forms. First, it enlisted, or in some cases, created, groups purporting to represent bar and restaurant owners, arguing that a smoking ban would hit their profits and, possibly, cause them to close. In fact, as a later systematic review showed, the only research showing that smoking bans reduced takings were those funded by the tobacco industry itself. ${ }^{3}$ Second, it appealed to the concept of personal freedom, arguing that smokers were being denied the right to do as they please. Obviously, this disregarded the right of non-smokers to be free from the effects of second-hand smoke. Third, it portrayed second-hand smoke as no more than an irritant, with little or no consequences for health. Moreover, it argued, falsely, that any irritation could be addressed easily by having separate smoking areas or improve ventilation. ${ }^{4}$

Tobacco control advocates often use the scream test. The tobacco industry, with its massive resources, is best placed to recognise which policies will damage its sales, or as public health professionals might say, reduce smoking. Consequently, the louder the industry protests about a proposed measure, the more effective it is likely to be. This was definitely the case with smoking bans. The industry poured vast resources into lobbying against them, employing the classic tactics of denialism. ${ }^{5}$ It engaged in a major operation to undermine the scientific basis for the bans. For example, Philip Morris operated a biological testing company in Germany, kept secret even within the corporation, with communications passed between the home addresses of those involved rather than through formal corporate channels. ${ }^{6}$ The intention was to create a climate of doubt around the growing evidence linking second-hand smoke to disease. Of course, the real test of smoking bans would come when they were implemented. Would they bring about improvements in health? In fact, the impact was far greater than almost anyone had anticipated.

The first evidence that smoking bans were having a major impact on health came from Helena, the capital of Montana. After it introduced a smoking ban in 2002, hospital admissions for myocardial infarction fell by $40 \%{ }^{7}$ This seemed quite remarkable, however, it should be noted that Helena has a small population and the confidence intervals were quite wide. Consequently, it was important to see if these results were replicated elsewhere. And they were. In Italy, a study in Piedmont reported an 11\% drop in admissions. ${ }^{8}$ A subsequent study for Italian regions reported $13 \%$ fewer admissions than predicted on the basis of previous trends, with the decline concentrated among men of working age, who were most likely to spend time in bars. ${ }^{9}$ Finally, a nationwide con- firmed the reduction, and though the overall effect was smaller, it was again greatest in younger people who are more likely to use bars. ${ }^{10}$ In 2014, a report by the US Surgeon General brought the existing evidence on smoking bans together and concluded that they were associated with an overall reduction in hospital admissions for myocardial infarction of between $12 \%$ and $18 \% .^{11}$

But surely, given this overwhelming evidence, the case for smoking bans is now firmly established? Apparently not. As recently as March 2017, one of the regular commentators in the British newspaper The Times, who also a member of the House of Lords, dismissed the findings from Helena, describing them as spurious correlation, before arguing that the vast majority of studies find no evidence that secondhand smoke causes heart attacks. The Helena effect was a fluke. ${ }^{13}$ Meanwhile, the populist UK Independence Party argues for rescinding the existing smoking ban. ${ }^{13}$ Fortunately, as a political party, it is so chaotic that it has no realistic chance of achieving power. Nonetheless, it is a reminder of the ability of what is now termed Fake News to gain traction among sections of the public.

This matters, because the struggle against tobacco is not yet won. The tobacco industry continues to produce misleading evidence, most recently in relation to the introduction of standardised packaging. The industry has commissioned reports to cast doubt on what is now recognised as the tremendous success of this measure in Australia, by means of highly selective analysis of the data. ${ }^{14}$ Many leading journals refuse to publish tobacco industry funded research, and with good reason. ${ }^{15}$

There is, however another worry. The tobacco industry is diversifying. It now dominates the market for electronic cigarettes and is blurring the boundaries between these products and traditional cigarettes, with products that heat rather than burn tobacco. There are considerable concerns about the industry's role in how these products are portrayed, and in particular in the production of the widely quoted, but unsubstantiated claim that they are $95 \%$ safer than ordinary cigarettes, ${ }^{16}$ a figure that constrasts starkly with mounting evidence of their harmful effects on the cardiovascular system. ${ }^{17,18}$ Yet, incredibly, a few tobacco control advocates seem willing to work with the tobacco industry to promote these products, ${ }^{19}$ seemingly unaware of how the industry has used scientists in the past. ${ }^{20}$

In 2016, Italy introduced a new package of tobacco control laws, including a ban on smoking in cars transporting children, prohibition of advertising of electronic cigarettes, and stricter regulations on tobacco-related litter. These are to be welcomed. However, there is still more to be done, including a ban on cigarette vending machines and standardised packaging, to take Italy once more to the forefront of tobacco control in Europe. When it does, it can expect strong opposition from the tobacco industry, which can be expected to produce lots of evidence supporting its case. Given its record, anything it says should be treated with the most extreme sceptcism. 
Correspondence: Martin McKee, London School of Hygiene and Tropical Medicine, 15-17 Tavistock Place, London, WC1H 9SH, UK.

Tel.: +44.20.7927.2229 - Fax: +44.20.7927.2701.

E-mail: martin.mckee@lshtm.ac.uk

Key words: tobacco, industry, ban.

Conflict of interest: the author declares no potential conflict of interest.

Received for publication: 16 March 2017.

Accepted for publication: 16 March 2017.

(C) Copyright M. McKee, 2017

Licensee PAGEPress, Italy

Journal of Public Health Research 2017;6:878

doi:10.4081/jphr.2017.878

This work is licensed under a Creative Commons Attribution NonCommercial 4.0 License (CC BY-NC 4.0).

\section{References}

1. Gorini G, Chellini E, Galeone D. What happened in Italy? A brief summary of studies conducted in Italy to evaluate the impact of the smoking ban. Ann Oncol 2007;18:1620-2.

2. Gallup Organisation Hungary. Survey on tobacco: analytical report. Brussels: European Commission; 2009.

3. Alamar B, Glantz SA. Effect of smoke-free laws on bar value and profits. Am J Public Health 2007;97:1400-2.

4. Drope J, Bialous SA, Glantz SA. Tobacco industry efforts to present ventilation as an alternative to smoke-free environments in North America. Tob Control 2004;13:i41-7.

5. McKee M, Diethelm P. How the growth of denialism undermines public health. BMJ 2010;341.

6. Diethelm PA, Rielle JC, McKee M. The whole truth and nothing but the truth? The research that Philip Morris did not want you to see. Lancet 2005;366:86-92.

7. Sargent RP, Shepard RM, Glantz SA. Reduced incidence of admissions for myocardial infarction associated with public smoking ban: before and after study. BMJ 2004;328:977-80.

8. Barone-Adesi F, Vizzini L, Merletti F, Richiardi L. Short-term effects of Italian smoking regulation on rates of hospital admission for acute myocardial infarction. Eur Heart $\mathrm{J}$
2006;27:2468-72.

9. Vasselli S, Papini P, Gaelone D, et al. Reduction incidence of myocardial infarction associated with a national legislative ban on smoking. Minerva Cardioangiol 2008;56:197-203.

10. Barone-Adesi F, Gasparrini A, Vizzini L, et al. Effects of Italian smoking regulation on rates of hospital admission for acute coronary events: a country-wide study. PloS One 2011;6:e17419.

11. US Surgeon General. The health consequences of smoking - 50 years of progress: a report of the Surgeon General. Atlanta, GA: US Department of Health and Human Services, Centers for Disease Control and Prevention, National Center for Chronic Disease Prevention and Health Promotion, Office on Smoking and Health; 2014.

12. Ridley M. My guide to avoiding an omnishambles budget: The Times; 2017. Available from: http://www.thetimes.co.uk/article/my-guide-to-avoiding-an-omnishambles-budgetqqufppsfs.

13. Morse FA. Nigel Farage Says Smoking Ban Silly And Illiberal: Huffington Post; 2013. Available from: http:/www.huffingtonpost.co.uk/2013/04/30/nigel-farage-smoking-ban-germanyn_ 3182909.html.

14. Laverty AA, Diethelm P, Hopkinson NS, et al. Use and abuse of statistics in tobacco industry-funded research on standardised packaging. Tob Control 2015;24:422-4.

15. McKee M, Allebeck P. Why the European Journal of Public Health will no longer publish tobacco industry-supported research. Eur J Public Health 2014;24:182.

16. McKee M, Capewell S. Evidence about electronic cigarettes: a foundation built on rock or sand? BMJ 2015;351:h4863.

17. Moheimani RS, Bhetraratana M, Yin F, et al. Increased cardiac sympathetic activity and oxidative stress in habitual electronic cigarette users: implications for cardiovascular risk. JAMA Cardiol 2017.

18. Liberman J, Wann S. E-cigarettes-what a practicing cardiologist needs to know. Am J Cardiol 2017;119:681-6.

19. Nocera J. When public health and big tobacco align. 2017. Available from: https://www.bloomberg.com/ view/articles/2017-03-09/when-public-health-and-big-tobacco-align.

20. Gruning T, Gilmore AB, McKee M. Tobacco industry influence on science and scientists in Germany. Am J Public Health 2006;96:20-32. 